\title{
STUDY ON REDUCTION OF IRON ORE CONCENTRATE IN ROTARY KILN TO PRODUCE DIRECT REDUCED IRON
}

\author{
STUDI REDUKSI KONSENTRAT BIJIH BESI DALAM TUNGKU \\ PUTAR MENGHASILKAN DIRECT REDUCED IRON
}

\author{
NURYADI SALEH and SITI ROCHANI \\ Research and Development Centre for Mineral and Coal Technology \\ Jalan Jenderal Sudirman 623 Bandung 40211 \\ Ph. (+6222) 6030483, Fax. (+6222) 6003373 \\ e-mail: nuryadi.saleh@esdm.go.id
}

\begin{abstract}
A direct reduced iron (DRI) was prepared using iron concentrate pellets and a coal as a reductant through three stages, namely, the first: iron concentrate pellets were dried by slow heating at $150^{\circ} \mathrm{C}$ to remove water content, the second: they were heated at $1,200^{\circ} \mathrm{C}$ to reduce magnetite into hematite which was treated in two different conditions, namely by oxygen and without oxygen injections; and the third: they were reduced in an atmosphere of $\mathrm{CO} / \mathrm{CO}_{2}$ at various temperatures of $950-1,200^{\circ} \mathrm{C}$. In this reduction process of iron oxide would be reduced by $\mathrm{CO}$ to metallic iron (Fe). The experimental results showed that the metallization without oxygen injection produced the best metallization at $1,100^{\circ} \mathrm{C}$ and the ratio of carbon/iron ( $\mathrm{FC} / \mathrm{Fe}$ ) of 0.52 to result $84.54 \%$, contained $74.68 \% \mathrm{Fe}$ and $88.34 \% \mathrm{Fe}_{\text {total }}$. The metallization by oxygen injection produced the best metallization at $1,100^{\circ} \mathrm{C}$, providing result of $96.81 \%, \mathrm{Fe}_{\text {metal }}$ of $87.88 \%$ and $90.78 \%$ of $\mathrm{Fe}_{\text {total }}$. The iron oxides on the DRI were relatively low, namely $2.9 \%$. In this research, prior pellets preparation a magnetic oxidation process on iron ore concentrate was also conducted and changed the magnetite into hematite. The reduction process on its pellets produced $94.15 \%$ metallization at $1,100^{\circ} \mathrm{C}$, and the $\mathrm{DRI}$ contained $97.85 \%$ of $\mathrm{Fe}_{\text {total }}, 85.32 \%$ of $\mathrm{Fe}_{\text {metal }}$ and $5.35 \%$ of $\mathrm{Fe}$ oxides. Furthermore, analyzing a remained carbon of the DRI using microscopy to seek the metal structure formed. The remained carbon was reported around $1-6 \% \mathrm{C}$. Next smelting process, it is suggested to have a high residual carbon concentration as there will be a carbon boil mechanism to reduce iron oxides that are still lagging on the DRI.
\end{abstract}

Keywords: sponge iron, direct reduction iron (DRI), rotary kiln, magnetic, hematite, reduction process, coal

\begin{abstract}
ABSTRAK
Telah dilakukan proses pembuatan direct reduced iron (DRI) dari pelet konsentrat besi dan batubara sebagai pereduksi melalui tiga tahapan proses yaitu pelet konsentrat besi dikeringkan dengan pemanasan lambat sampai suhu $150^{\circ} \mathrm{C}$ untuk menghilangkan kandungan air, proses reduksi magnetik menjadi hematit dengan dua cara yaitu pelet kering diindurasi pada suhu $1.200^{\circ} \mathrm{C}$ pada dua kondisi, yaitu dengan injeksi $\mathrm{O}_{2}$ dan tanpa menginjeksikan $\mathrm{O}_{2}$, dan terahir pelet direduksi dalam atmosfir gas $\mathrm{CO} / \mathrm{CO}_{2}$ pada variasi suhu $950-1.200^{\circ} \mathrm{C}$. Pada proses reduksi ini besi oksida akan direduksi oleh gas CO menjadi logam besi (Fe). Hasil percobaan menunjukkan bahwa metalisasi pada indurasi tanpa oksidasi menghasilkan metalisasi terbaik yang dicapai pada suhu $1.100{ }^{\circ} \mathrm{C}$ dan perbandingan fixed karbon/besi ( $\mathrm{FC} / \mathrm{Fe}$ ) 0,52 yaitu 84,54\%, dengan kandungan $\mathrm{Fe}_{\text {logam }} 74,68 \%$, serta $F e_{\text {total }}$ dalam $\mathrm{DRI}$ mencapai $88,34 \%$. Metalisasi pada indurasi dengan oksidasi (injeksi $\mathrm{O}_{2}$ ) menghasilkan metalisasi terbaik pada suhu $1100^{\circ} \mathrm{C}$, yaitu 96,81\%, Fe metal $87,88 \%$ dan Fe total 90,78\%, serta Fe oksida yang sudah relatif rendah yaitu $2,9 \%$. Pada penelitian ini juga dilakukan proses oksidasi magnetik menjadi hematit sebelum dibuat pelet menghasilkan metalisasi $94,15 \%$ pada suhu $1.100{ }^{\circ} \mathrm{C}$ dengan $\mathrm{Fe}$ total 97,85\%, Fe metal 85,32\% dan Fe dalam bentuk oksida 5,35\%. Selain itu dilakukan analisis kandungan karbon sisa dan mikroskopi sayatan poles DRI menghasilkan penampakan struktur logam yang terbentuk dan karbon sisa berkisar antara 1-6\% C. Karbon sisa sebaiknya mempunyai kadar tinggi karena pada
\end{abstract}


proses peleburan selanjutnya terdapat mekanisme carbon boil untuk dapat lebih mereduksi kembali besi oksida yang masih tertinggal dalam DRI.

Kata kunci: sponge iron, direct reduction iron (DRI), tungku putar, magnetik, hematit, proses reduksi, batubara.

\section{INTRODUCTION}

Direct reduced iron (DRI) is an iron ore processing products through a direct reduction of iron concentrates, in either the form of granules, pellets, or lump with a gas as a reductant such as a natural gas of $(\mathrm{CO}+$ $\mathrm{H}_{2}$ ) or coal, accomplished at $800-1,050^{\circ} \mathrm{C}$, below the melting point of iron $\left(1,536^{\circ} \mathrm{C}\right)$. even though utilizing process wastes containing significant amounts of iron and carbon such as sludge, dust, and scale to optimize raw materials usage and lower production costs is also possible to produce a DRI (Chung, Kim and Sohn, 2015).

These products are often referred as sponge iron, because of its physical appearance looks like a sponge (porous). Direct reduction is an alternative process in iron making has been developed to overcome some difficulties of a conventional process, such as sintering raw material, coke ovens, blast furnaces, and basic oxygen furnaces, which require high investment as well as strict raw material specifications. Direct reduction process has advantages as energy-efficient and it is competitive compare to the blast furnace especially when it is integrated with an electric arc furnace (EAF) due to capturing the heat on the DRI.

DRI or sponge iron composition consists of iron metal and slag; when it is processed in hot conditions in an EAF to separate ferrous metals from its slag in terms of producing the pig iron. Later the pig iron is processed to produce steel through oxidation blowing in a converter. Typical chemical compositions of $\mathrm{DRI}$ as follows: $90-94 \% \mathrm{Fe}_{\text {total }}, \quad 83-90 \%$ $\mathrm{Fe}_{\text {metal }}, 92-96 \%$ metallization, 1.0 to $2.5 \% \mathrm{C}$, 0.005 to $0.9 \% \mathrm{P}_{2} \mathrm{O}_{5}, 0.001-0.03 \% \mathrm{~S}, 2.8-$ $6 \%$ mineral oxides $\left(\mathrm{CaO}, \mathrm{Al}_{2} \mathrm{O}_{3}, \mathrm{SiO}_{2}, \mathrm{MgO}\right)$. The oxide minerals are present on the steelmaking slag.

There are three types of direct reduction technologies which has been developed in the world using a feed in the form of pellets or lumps. First, using a shaft furnace (SF) with natural gas as a reductant; the second, using a rotary kiln (RK) with coal as a reductant; and the third, using a rotary hearth furnace (RHF) with coal or natural gas as a reductant. The technology with a shaft furnace named as HYL III. It is commercialized at PT. Krakatau Steel Cilegon, and Midrex (Atsushi, Uemura and Sakaguchi, 2010). The technology using a rotary kiln named as SL/RN and is applied at PT. Meratus Jaya, South Kalimantan. The feed size is about $10 \mathrm{~mm}$.

Several problems have been faced by iron and steel manufacturing industries. The costeffectiveness analysis of $H Y L$ and Midrex DRI technologies for the Iron and steelmaking industry was studied and discussed (Baig and Murray, 2016). In Indonesia, applying the HYL III technology face a high price of the natural gas and supplying raw materials such as iron pellets that are imported (from Brazil). While applying the $\mathrm{SL} / \mathrm{RN}$ technology as used by PT. Meratus Jaya deal with expensive ore transport due to the persistence of poor infrastructure. In addition the type of minerals in the iron ore as the feed consists of hematite and magnetite, which affects to the product quality as a result of ore reduction as well as degradation of granules that causes dusting. Nowadays, the DRI making using a rotary kiln technology is still not showing an optimum result. Therefore, development and innovation of the process are needed, especially raw material processing prior to feed into the rotary kiln. On the other hand, a large amount of DRI is needed to supply steelmaking at PT. Krakatau Steel in terms of substituting imported pellets or scrap.

The ratio of coal versus iron ore and grain size of the feed are very important to control the increase of the reduction process in DRI making. Several studies have been done such as by Dey, Prasad and Singh (2015) who studied the manufacture of sponge iron using various coals from India, the loss of energy and the efficiency improvement of the sponge iron manufacturing process. Man et al. (2014), examined the reduction process by varying the ratio of iron ore to coal in the 
reduction temperature between $500-1,200^{\circ} \mathrm{C}$ by thermogravimetric, in addition to the effect of the grain size studied. The ratio of ore to carbon composites are also studied by Kawanari et al. (2011) by increasing the reduction rate. It was reported that nanosized particles can be reduced at a temperature of $650^{\circ} \mathrm{C}$ within a few minutes. $\mathrm{Yu}$ et al. (2014) studied the ore reduction, which contained high-phosphorus oölitic hematite prior to magnetic separation. They studied the effect of size, strength, and reduction of coal briquettes composite.

El-Hussiny et al. (2015) examined Baharia iron ore using hydrogen as a reducing agent and studied its kinetic reduction rate to yield reduction control through a thin layer of ash with an activation energy of $60.55 \mathrm{KJ} / \mathrm{mol}$. This research was supported by Hashem et al. (2015) who also studied ore from Baharia to see the kinetic reduction in the temperature range from 700 to $950^{\circ} \mathrm{C}$. The result showed that of the best temperature reduction was $950^{\circ} \mathrm{C}$.

The aim of this research is to study the process of the iron ore reduction using the $\mathrm{CO}$ gas produced from coal as a reductant in a rotary kiln. The iron ore and the coal were taken from South and East Kalimantan respectively. There are two main reasons in accomplishing this study. First, the availability of iron ore as raw material is abundance. Second refers to the availability of coal in a large deposit, especially in Eastern Kalimantan. Coal is a source of energy for the power plant as well as a reductant, which has not been utilized optimally in industrial processing of metallic minerals, especially through the use of coal directly. Another reason which is encouraging to conduct the study is the minerals value-added as mandated by Law No. 4 of 2009 on mineral and coal. Such the mandate requires to conduct minerals processing and purification in the country. Consequently, the iron sponge is one of the iron ore purification products that can be exported, with the limit quality, namely around $\geq 75 \%$ Femetal as listed in the ESDM regulation no. 25/2018 which stated on Limitations of minimum processing and refining metal mineral commodities in the country.

\section{METHODS}

The flow diagram of the experiments is illustrated in Figure 1. The main materials used in this study were coal and iron ore concentrate. The iron concentrate in the form of dry pellets is used as the feed. The pellets which have $10-12 \mathrm{~mm}$ in size, contained $68.1 \%$ Fetotal, and were dried at room temperature for 24 hours. The coal for this study contained $43.64 \%$ carbon and $6466 \mathrm{cal} / \mathrm{g}$.

The pellets are a mixture of magnetite iron concentrate and coal as a reductant in the ratio of Fixed Carbon/Iron ( $\mathrm{FC} / \mathrm{Fe}$ ) from 0.22 to 0.52 and reduction temperature of $1,100^{\circ} \mathrm{C}, 1,050^{\circ} \mathrm{C}, 1,000^{\circ} \mathrm{C}$ and $950^{\circ} \mathrm{C}$. Reduction time was set for 2 hours. To strengthen the composite pellets, the outer layer of the pellets were coated with a thin layer of concentrate.

The iron ore concentrate in the form of pellets was reduced using a rotary kiln. The process took place through three stages, namely

1. Iron concentrate pellets were dried by slow heating at $150^{\circ} \mathrm{C}$ (to keep the pellets are not broken), at this stage, the moisture should be eliminated;

2. The dry pellets were hardened at $1,200^{\circ} \mathrm{C}$ in two ways, namely by oxygen injection and without oxygen injection. This phase aimed to convert the magnetite into hematite;

3. The pellets were then reduced under $\mathrm{CO} / \mathrm{CO}_{2}$ atmosphere at $1,200^{\circ} \mathrm{C}$. In this process, the iron oxide would be reduced by the $\mathrm{CO}$ gas to metallic iron ( $\mathrm{Fe})$.

Some experiments were also conducted by oxidating magnetite-into-hematite iron concentrates before producing the pellets. The pellets were then made by mixing hematite and coal ( $\mathrm{FC} / \mathrm{Fe} 0.42$ and 0.32 ) with $0.5 \% \mathrm{CMC}$ as a binder. The reduction process was similar to the process as mentioned above.

The best achievement of the reduction process was measured from the reduction and metallization percentages, which could be calculated by the following equations:

$\mathrm{RP}=\frac{\mathrm{LW}}{\mathrm{TOW}_{\max }} \times 100 \%$ 

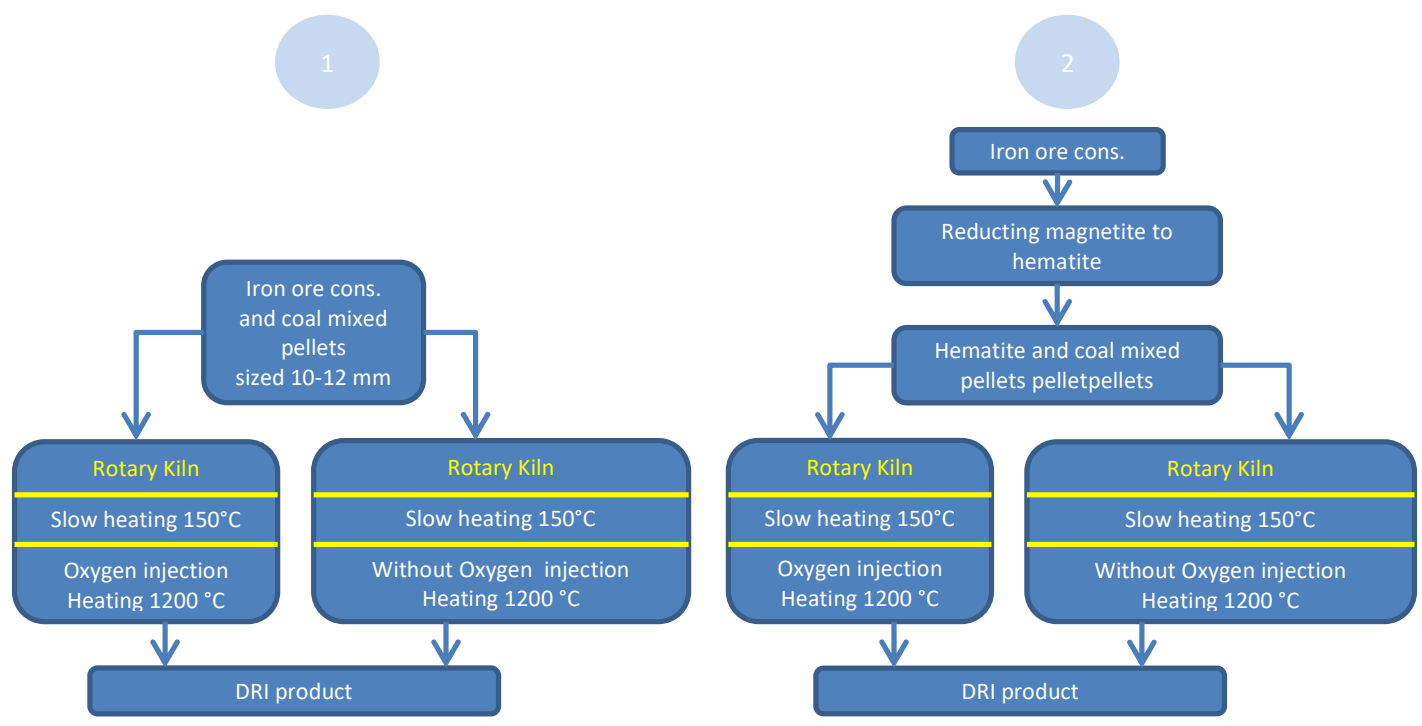

Figure 1. Flow diagram for DRI making

$$
\begin{aligned}
& \mathrm{RP}=\text { Reduction, (\%) } \\
& \mathrm{LW} \quad=\text { Losing weight, } \mathrm{g} \\
& \mathrm{TOW}_{\max }=\text { Total maximum oxygen weight } \\
& \text { that can be theoretically } \\
& \text { eliminated, } g \\
& \mathrm{MP}=\frac{\mathrm{Fe} \mathrm{e}_{\text {metal }}}{\mathrm{F} \mathrm{e}_{\text {tot }}} \times 100 \% \\
& \mathrm{MP}=\text { Metallization, } \% \\
& \mathrm{Fe}_{\text {metal }}=\text { Iron metal content in the DRI,\% } \\
& \mathrm{Fe}_{\text {tot }}=\text { Total iron content in the DRI,\% }
\end{aligned}
$$

\section{RESULTS AND DISCUSSIONS}

The coal used in this study can be categorized as medium calorific value, came from Eastern Kalimantan and it was used as a carbon reductant source (CO gas). Its characteristics are shown in Table 1.

Tabel 1. Analysis result of coal

\begin{tabular}{ccc}
\hline Parameter & Content (\%) & Description \\
\hline Fixed carbon & 43.64 & \\
Total moisture & 14.20 & \\
Inherent moisture & 11.68 & \\
Volatile matter & 41.79 & \\
\hline Total sulfur & 0.59 & dry basis \\
& 0.87 & as received \\
\hline Calorific value & $5.282 \mathrm{Cal} / \mathrm{g}$ & as received \\
& $6.466 \mathrm{Cal} / \mathrm{g}$ & as dried \\
& $7.552 \mathrm{Cal} / \mathrm{g}$ & dry as free \\
& & basis \\
\hline & &
\end{tabular}

The characterization of the iron concentrate was performed by the atomic absorption spectrophotometer and other analytical methods are shown in Table 2. This concentrate was formed as pellets for reduction feed.

Table 2. Analytical results of iron concentrate

\begin{tabular}{cc}
\hline Compound/element & Content (\%) \\
\hline $\mathrm{Fe}_{\text {total }}$ & 68.1 \\
$\mathrm{SiO}_{2}$ & 1.62 \\
$\mathrm{Al}_{2} \mathrm{O}_{3}$ & 1.18 \\
$\mathrm{CaO}$ & 2.28 \\
\hline
\end{tabular}

In this study; for making the sponge iron, three process steps were accomplished, namely heating the pellets to remove the water content, reduction process that converts magnetite to hematite (Gorbachev, Abzalov and Yurév, 2007) and hematite-tometallic iron reduction by a $\mathrm{CO} / \mathrm{CO}_{2}$ which reduces gas generation from the coal. Several trials had also been conducted for the reduction process at 10-12 $\mathrm{mm}$-sized pellets using hydrogen gas as a reductant. The period time required for the reduction process was shorter than using coal as shown in Table 3.

It is clear that the reduction process using hydrogen gas requires lesser time and lower temperature compared to that of coal, however, it is more difficult in handling the hydrogen gas and the price is more 
expensive than that of the coal. Thus, the coal was used for the next experiments. In addition; to the commercialization of the process, the coal is widely available in the country.

Table 3. Reduction of iron ore concentrate with different reductants (coal and hydrogen gas)

\begin{tabular}{cccc}
\hline No. & Reductant & Temp., ${ }^{\circ} \mathrm{C}$ & Time, hour \\
\hline 1 & Coal & 1,075 & 2.5 \\
2 & Coal & 1,000 & 4 \\
3 & $\mathrm{H}_{2}$ Gas & 900 & 1 \\
4 & $\mathrm{H}_{2}$ Gas & 1,000 & 0.42 (25 minutes) \\
\hline
\end{tabular}

In the first phase by heating the pellets slowly at a temperature of $150^{\circ} \mathrm{C}$, to keep the pellets from shattering pellets. At this stage, the pellet's moisture would be released. This would facilitate the process. In the second phase, there would be a transformation of magnetite into hematite iron. This occurred when the pellet combustion by injecting oxygen gas. The next would be a metallization process.

In principle, the reduction reaction of iron oxide with the $\mathrm{CO}$ gas to a metallic iron based on reactions as follows:

$3 \mathrm{Fe}_{2} \mathrm{O}_{3}+3 \mathrm{CO} \rightarrow 2 \mathrm{Fe}_{3} \mathrm{O}_{4}+\mathrm{CO} \Delta \mathrm{H}_{1}=-12.85 \mathrm{Kcal} \ldots \ldots . . .(1)$

$\mathrm{Fe}_{3} \mathrm{O}_{4}+\mathrm{CO} \rightarrow 3 \mathrm{FeO}+\mathrm{CO}_{2} \Delta \mathrm{H}_{2}=+9.76 \mathrm{Kcal}$...............(2)

$\mathrm{FeO}+\mathrm{CO} \rightarrow \mathrm{Fe}+\mathrm{CO}_{2} \Delta \mathrm{H}_{3}=-6.85 \mathrm{Kcal}$.

The reductant that $\mathrm{CO}$ gas generated from the combustion of coal as a source of carbon $(\mathrm{C})$ is based on the reaction of [4 and 5 ]:

$\mathrm{C}+1 / 2 \mathrm{O}_{2} \rightarrow \mathrm{CO} \Delta \mathrm{H}_{4}=-94.05 \mathrm{Kcal}$

$\mathrm{C}+\mathrm{O}_{2} \rightarrow \mathrm{CO}_{2} \Delta \mathrm{H}_{5}=25.42 \mathrm{Kcal}$

The thermodynamic enthalpy change $(\Delta H)$ in Reaction (2) shows positive values (endothermic), namely $\Delta \mathrm{H}_{2}=+9.76 \mathrm{Kcal}$, which means that the reaction requires energy from outside of the system so that the reduction process dealing with wüstite or magnetite iron (FeO) formation took place. Furtherly, the wüstite will change to metallic iron $(\mathrm{Fe})$. Reduction reaction of the iron mineral into the metallic iron can thermodynamically be held with a negative change in the enthalpy value (exothermic) which emits the thermal energy systems.

Magnetite iron metallization at temperatures below $1,000^{\circ} \mathrm{C}$ is very unlikely to produce the metallization of more than $90 \%$, because the enthalpy formation is endothermic, so the magnetite iron metallization at high temperatures $1,100^{\circ} \mathrm{C}$ only ranges between $80-90 \%$.

In this experiment, the methods applied in the reduction process was set to produce DRI with the following qualities: the metallization as high as possible (>90\%) the oxide impurities as low as possible $\left(\mathrm{Al}_{2} \mathrm{O}_{3}+\right.$ $\mathrm{SiO}_{2}<5 \%$ ); and the sulfur content as low as possible $(S<0.05 \%)$.

In the reduction process, it was expected that all $\mathrm{Fe}_{3} \mathrm{O}_{4}$ would be reduced into metallic iron. If the oxygen lost was calculated theoretically it was as much as $25.9 \% \mathrm{O}_{2}$ of $68.1 \% \mathrm{Fe}$ content. Meanwhile, the $\mathrm{SiO}_{2}$, $\mathrm{Al}_{2} \mathrm{O}_{3}$ and $\mathrm{MgO}$ remained largely unchanged forms, however the apatite compound transformed into $\mathrm{P}$ so did the FeS into $\mathrm{S}$. Maximum oxygen loss calculation due to reduction process is shown in Table 4.

The DRI type which is commercially used in the steelmaking process to substitute scrap can be classified into three grades as shown in Table 5.

Table 4. The maximum oxygen loss calculation due to the reduction process

\begin{tabular}{cccccc}
\hline $\begin{array}{c}\text { Compound/ } \\
\text { element }\end{array}$ & Mass, \% & $\begin{array}{c}\text { Compound before } \\
\text { reduction }\end{array}$ & Oxygen content & $\begin{array}{c}\text { Compound after } \\
\text { reduction }\end{array}$ & Oxygen loss \\
\hline $\mathrm{Fe}$ & 68.1 & $\mathrm{Fe}_{3} \mathrm{O}_{4}$ & 25.9 & $\mathrm{Fe}$ & 25.9 \\
$\mathrm{SiO}_{2}$ & 1.62 & $\mathrm{SiO}_{2}$ & constant & $\mathrm{SiO}_{2}$ & 0 \\
$\mathrm{Al}_{2} \mathrm{O}_{3}$ & 2.28 & $\mathrm{MgO}$ & constant & $\mathrm{Al}_{2} \mathrm{O}_{3}$ & 0 \\
$\mathrm{MgO}$ & & constant & $\mathrm{MgO}_{3}$ & $\mathrm{P}$ & \\
$\mathrm{P}$ & $\mathrm{FeS}$ & & $\mathrm{S}$ & 25.9 \\
$\mathrm{~S}$ & 73.0 & & 98.98 & & \\
Total & 26.92 & $\mathrm{~K}_{2} \mathrm{O}+\mathrm{CaO}$ & 1.02 & & \\
others & & &
\end{tabular}


Table 5. Classification of DRI (Direct Reduced Iron)

\begin{tabular}{ccc}
\hline DRI types & $\mathrm{Fe}_{\text {total }}, \%$ & Metallization, \% \\
\hline Grade-A & $>88$ & $90-98$ \\
Grade-B & $80-86$ & $84-90$ \\
Grade-C & $<80$ & $<84$ \\
\hline
\end{tabular}

\section{Metallization on Induration without Oxidation (Without Oxygen Injection)}

The best reduction process was indicated by a DRI the metallization above $90 \%$. The experimental results of reduction appeared that all of the tests series with a varies ratio $\mathrm{FC} / \mathrm{Fe}$ of 0.22 to 0.52 and reduction temperature at $950-1,000^{\circ} \mathrm{C}$, could not reach metallization more than $90 \%$; for example the reduction temperature at $950^{\circ} \mathrm{C}$, the metallization only reached up to $20 \%$, and at $1,000^{\circ} \mathrm{C}$ attained up to $54 \%$ metallization as shown in Figure 2. This steep metallization at $\mathrm{FC} / \mathrm{Fe}$ range $0.4-0.5$ occurred at $1,000^{\circ} \mathrm{C}$ due to the availability of carbon to reduce iron into metal. Referring to coal used for reducing agents containing fixed carbon about $43.64 \%$, this can be related to the availability of carbon for reduction at temperatures starting from $1,000^{\circ} \mathrm{C}$.

Reduction experiment at $1,100^{\circ} \mathrm{C}$ and $\mathrm{FC} / \mathrm{Fe}$ 0.52 reached up to $84.54 \%$, with a metal content of $74.68 \% \mathrm{Fe}$, as well as total $\mathrm{Fe}$ in the DRI reached up to $88.34 \%$. Therefore, there was still $13.665 \% \mathrm{Fe}$ available in the form of oxide, slagged in DRI, as shown in Figure 3.

\section{Metallization on Induration by Oxidation $\left(\mathrm{O}_{2}\right.$ Injection)}

The improvement process was proposed to increase metallization in the DRI. The magnetic pellet was used and it was treated by oxygen injected with a flow rate of 3 liters/minute. This was intended to convert the magnetite into hematite. In addition, oxygen injection was aimed to improve the physical properties of the pellets as shown by the result of the research by Alizadeh (2012) that suggested that the injected oxygen into the furnace in a specific range of time and temperature, would shorten the heating time and increase the production rate of the iron ore pellets reduction.
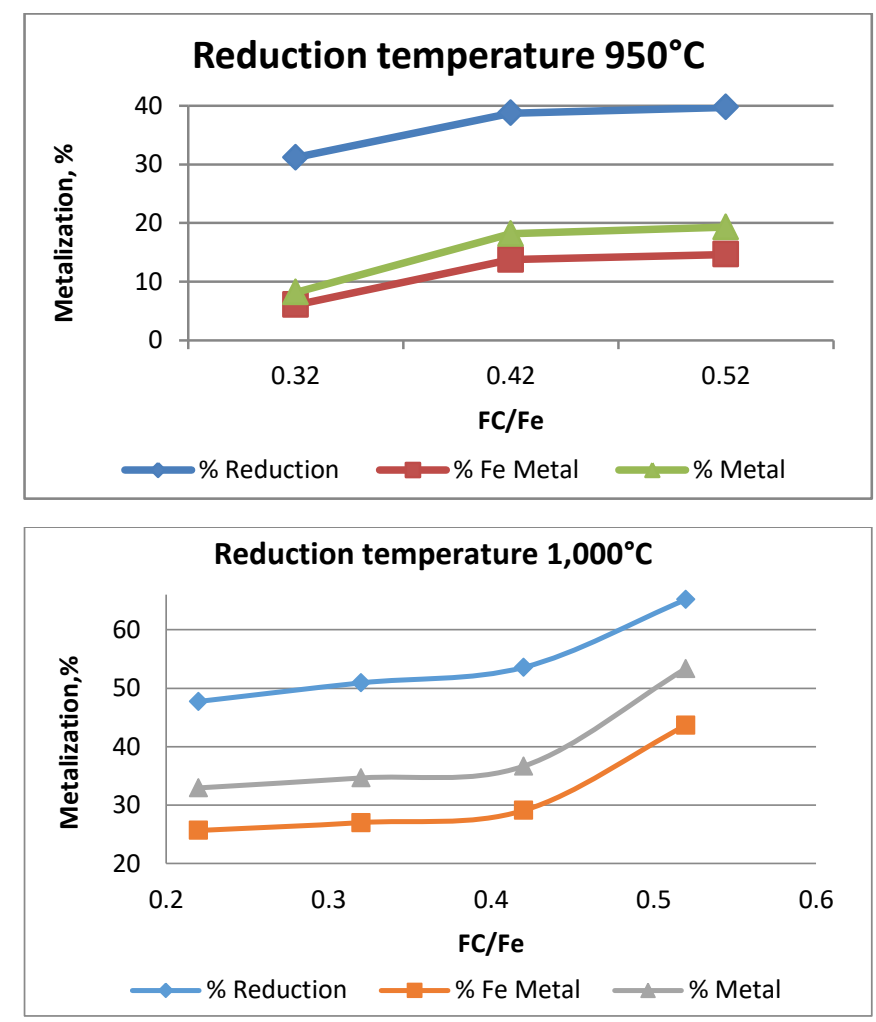

Figure 2. Performance of magnetite pellets reduction at $950^{\circ} \mathrm{C}$ and $1,000^{\circ} \mathrm{C}$ 


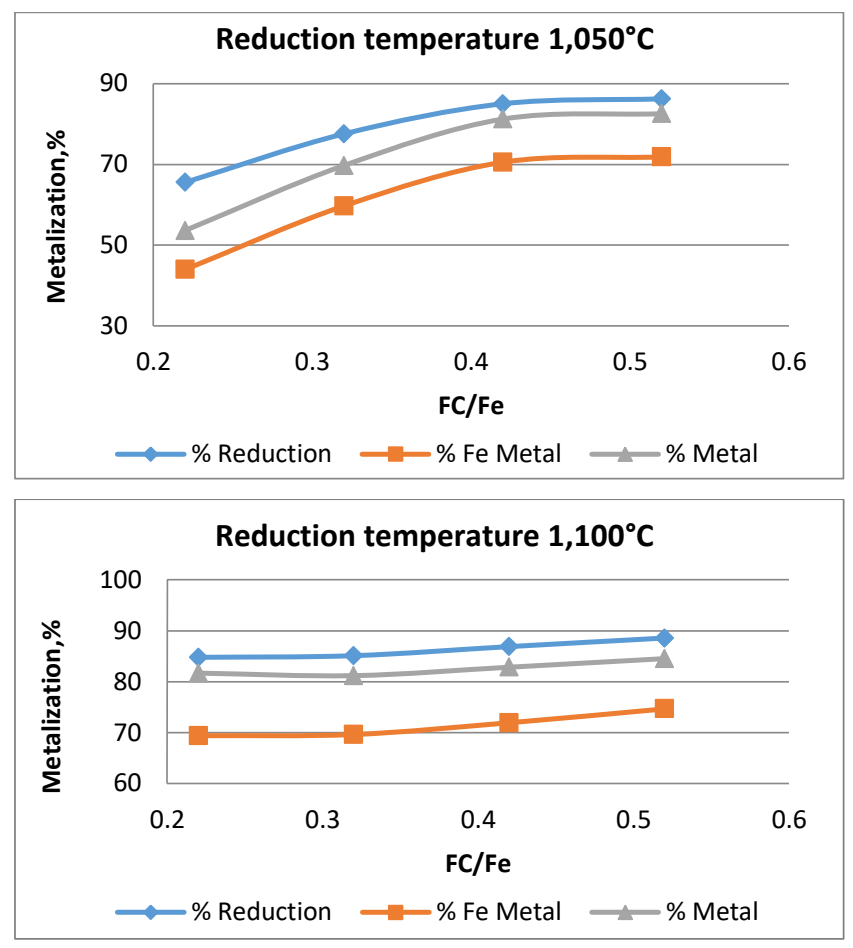

Figure 3. Magnetite pellets reduction performance at a temperature $1,050^{\circ} \mathrm{C}$ and $1,100^{\circ} \mathrm{C}$

The change of magnetite into hematite phase caused the reduction reaction turned out to be exothermic. Therefore the generated heat could drive the endothermic reaction of $\mathrm{FeO}$ to $\mathrm{Fe}$ and could create more extensive reaction (Reaction 3 ). The performance reduction process oxidized magnetite pellet is shown in Figure 4. The above $90 \%$ metallization could be achieved at lower temperatures, i.e. $1,050^{\circ} \mathrm{C}$. The metallization could reach $93.86 \%$.The iron metal content in the $\mathrm{DRI}$ reached up to 84.84\% $\mathrm{Fe}$ and $90.39 \% \mathrm{Fe}_{\text {total. }}$. In the DRI, the $\mathrm{Fe}$ oxide forms were $5.55 \%$.

When the temperature reduction was increased $1,100^{\circ} \mathrm{C}$, then the metallization was raised which was noted at $96.81 \%$ metallization, 87.88\% $\mathrm{Fe}_{\text {metal }}$ and $90.78 \%$ $\mathrm{Fe}_{\text {total }}$. Fortunately, the iron oxide content was relatively low (2.9\%). At lower reduction, temperatures below $1,050^{\circ} \mathrm{C}$, the metallization $>90 \%$ could not be reached, as shown in Figure 5.

At lower temperatures (under $1,050^{\circ} \mathrm{C}$ ), metallization of $>90 \%$ could be not reached, as shown in Figure 5.

\section{Metallization on Iron-Ore-Concentrate- Based Pellets}

The development process was also accomplished by oxidation of magnetite into hematite prior to produce pellets. Magnetite concentrate was oxidized to hematite mixed with coal at the ratio of 0.42 and 0.32 with $0.5 \%$ CMC binder. Based on visual experience it was observed that the pellets in a wet-formed (green pellets) of the composite do not own a good strength (low green strength). Therefore resurfacing with hematite on the surface is requisited. It was required about $1 \mathrm{~kg}$ hematite to coat a 10 $\mathrm{kg}$ composite pellets. This coating was also intended that during oxygen induration, the pellet has not been oxidized. However, this simulation had not accomplished for coated composites pellets, since the composite pellets were directly reduced. Reduction pellets coated composite performance is shown in Figure 6. It resulted that $>90 \%$ of metallization could be achieved at temperatures of $1,000^{\circ} \mathrm{C}$, i.e. $91.6 \%$ metallization, 95.19\% $\mathrm{Fe}_{\text {total }}$ and $82.6 \%$ $\mathrm{Fe}_{\text {metal }}$ and the oxide was noted at $7.58 \%$. Higher temperatures could lead to rise metallization up to $94.15 \%$ metallization at $1,100^{\circ} \mathrm{C}$ with $97.85 \% \mathrm{Fe}_{\text {total }}, 85.32 \% \mathrm{Fe}_{\text {metal }}$ and $5.35 \%$ oxide form. 
INDONESIAN MINING JOURNAL Vol. 22, No. 2, October $2019: 87$ - 98
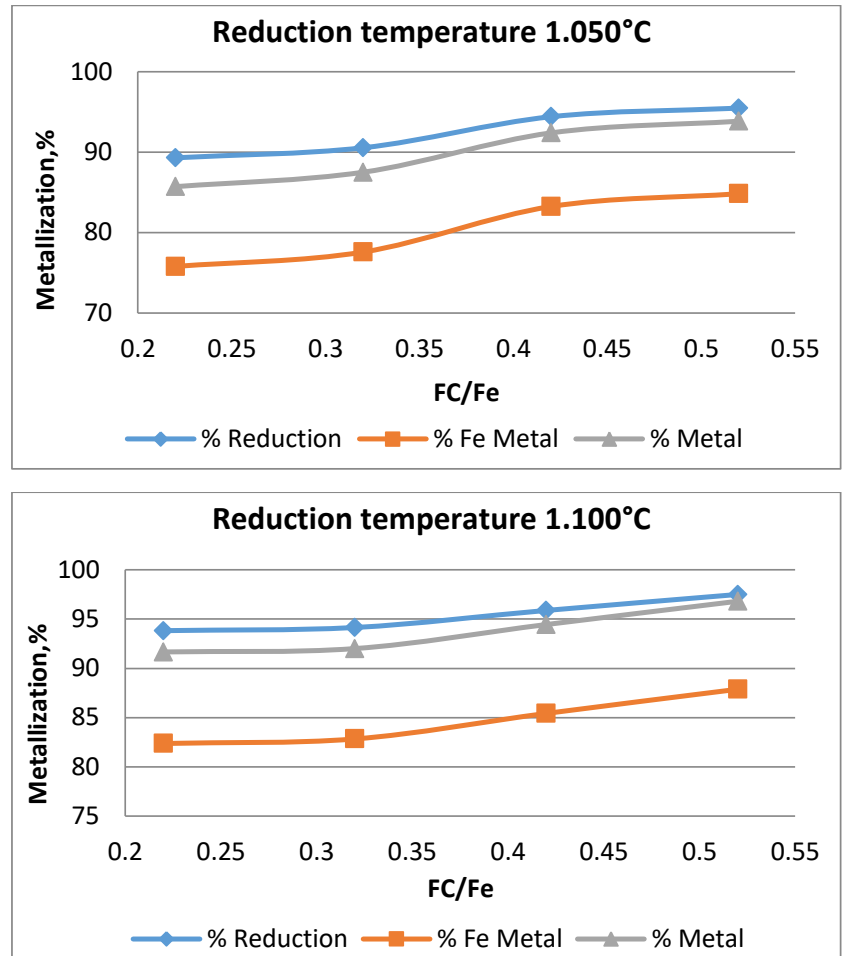

Figure 4. Reduction performance of oxidized magnetite pellets at $1,050^{\circ} \mathrm{C}$ and $1,100^{\circ} \mathrm{C}$
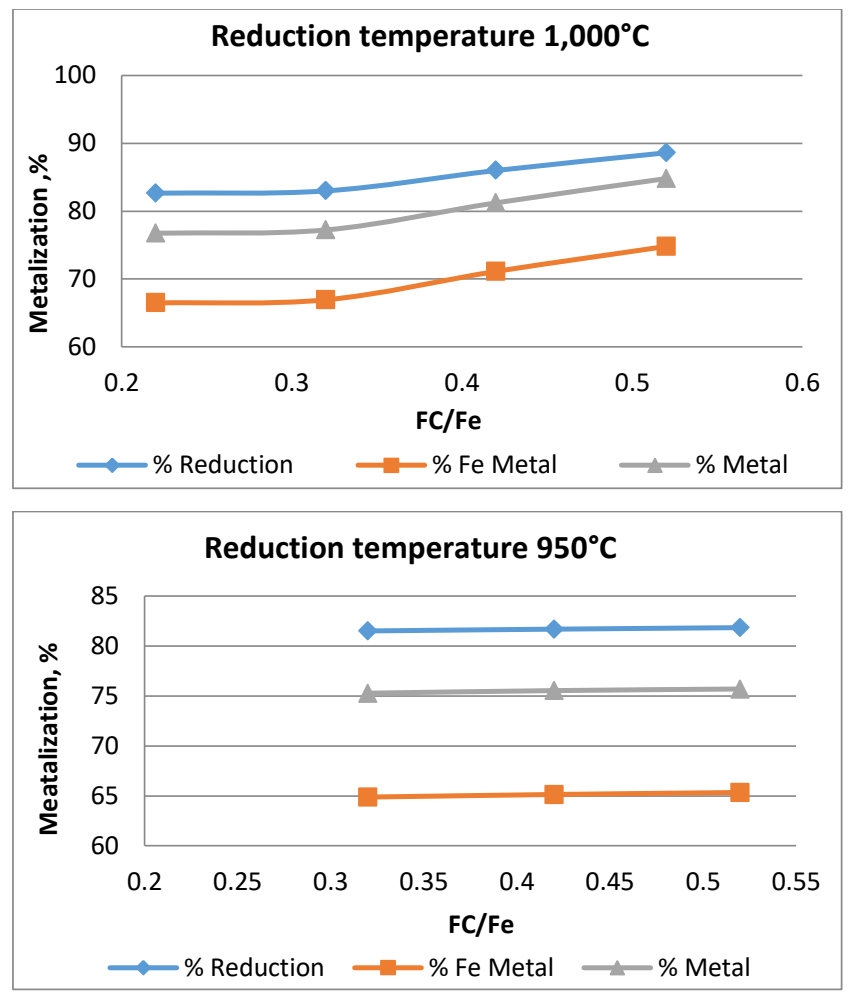

Figure 5. Reduction performance of oxidized magnetite pellets at $1,000^{\circ} \mathrm{C}$ and $950^{\circ} \mathrm{C}$ 

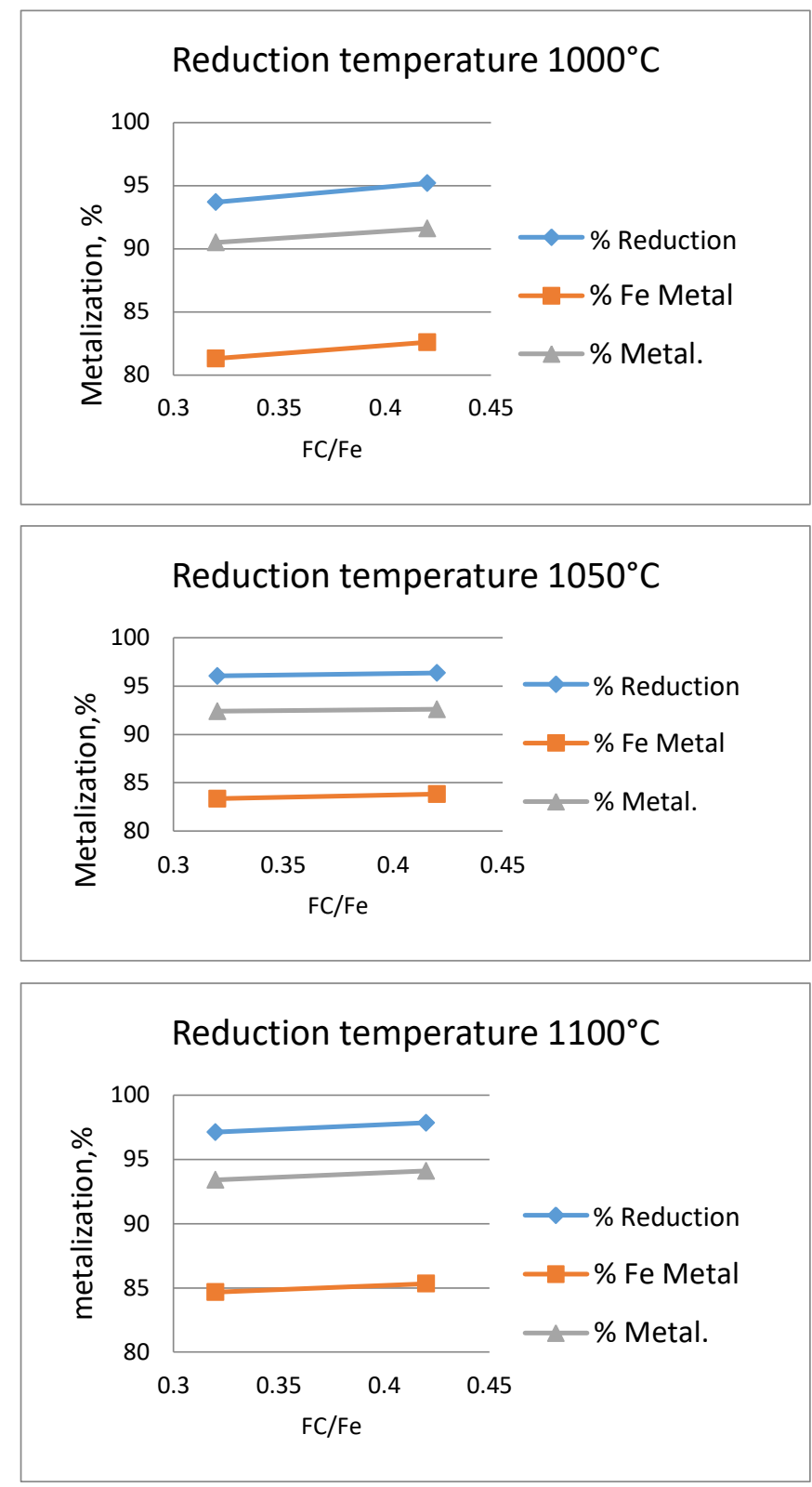

Figure 6. Reduction performance of hematite pellets composite at $1,000,1,050$, and $1,100^{\circ} \mathrm{C}$.

\section{Residual Carbon Content and DRIs Polished Section Microscopy}

DRI pellets from residual carbon composites were also analyzed. Remained carbon has a preference at higher content since it could have a benefit in the melting process on carbon boil mechanism to further reduce of Fe oxides that were still lagging in the DRI. The remained carbon ranged from 1 to $6 \% \mathrm{C}$ in DRI.

Microscopic examinations show the extend of reaction reduction process from the outer to the inner part of a pellet sample (Figures 7 and 8). It showed that a very solid metal appearance at the outer part of the pellets, and then towards the middle, the metal appearance began to decline. 


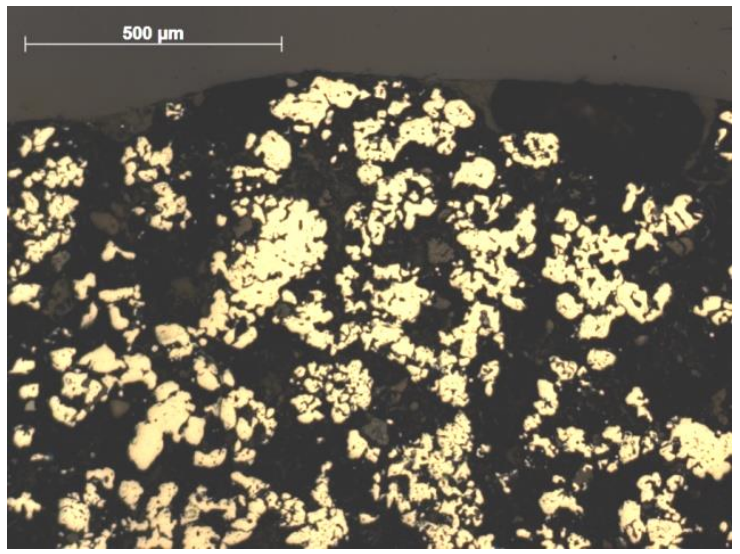

Figure 7. Photomicrograph of DRIs polished section (Metallization is seen denser on the outside of the pellets)

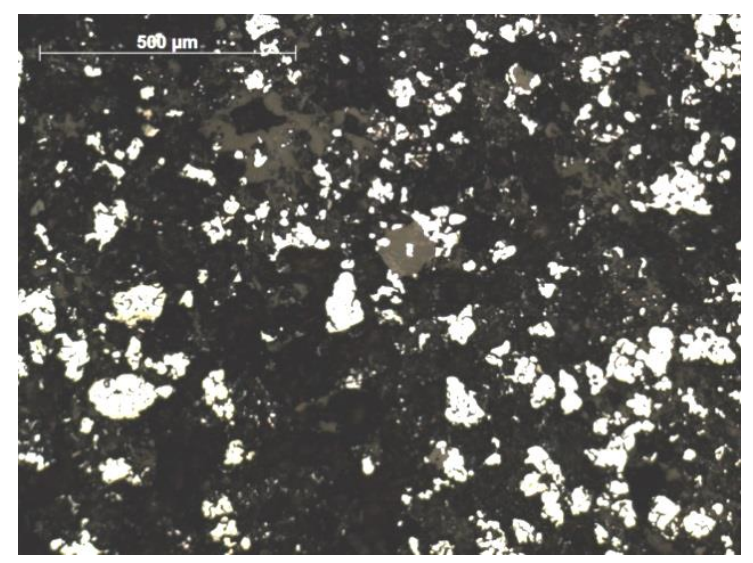

Figure 8. Photomicrograph of DRIs polished section (Metallization is seen less dense in the center of the pellets)

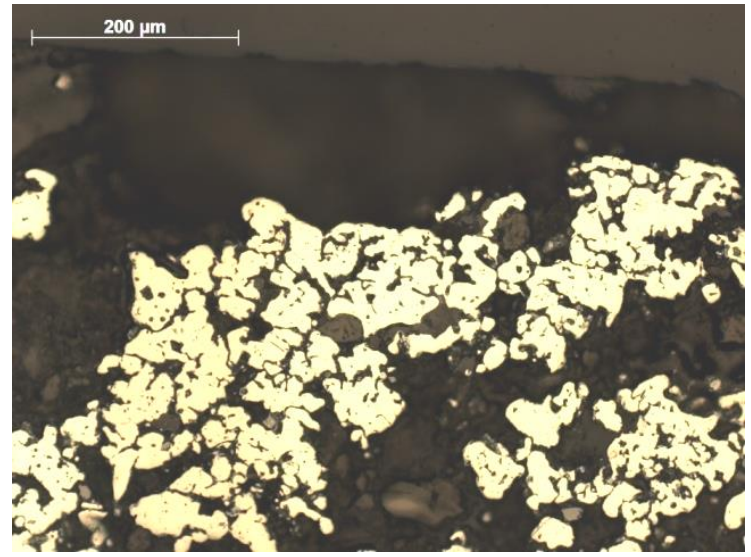

Figure 9. Photomicrograph of DRIs polished section (metal structure has appeared on the outside of the pellets) 


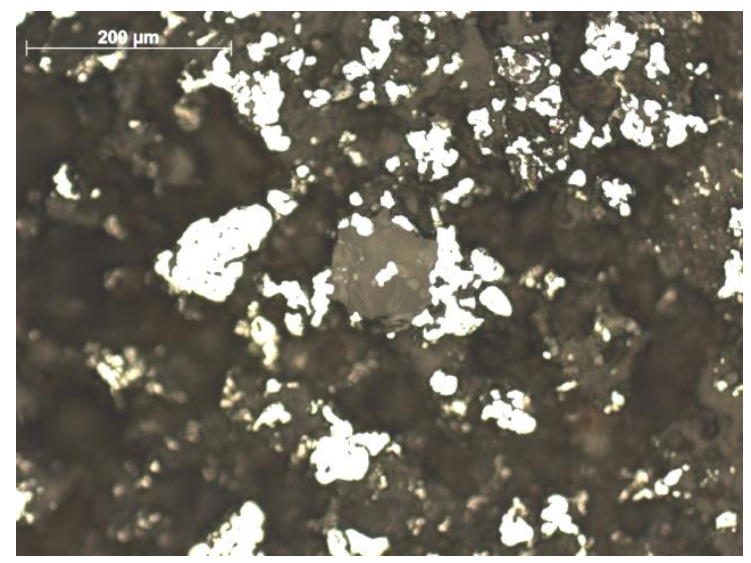

Figure 10. Photomicrograph of DRIs polished section (Metal structure is seen at the center of the pellets)

\section{CONCLUSION}

Research on producing the DRI from iron concentrate using coal as a reductor through the reduction process of dry pellets treated with and without oxygen injection has produced DRI Grade A and grade B respectively.

In addition, prior pellets preparation a magnetic oxidation process on iron ore concentrate to change the magnetite into hematite before the reduction process also produces DRI grade $A$.

Classification of $D R I$ in the form of grade $A$, $B$, and $C$ have been acceptable by steel manufacturers as a scrap substitution.

\section{ACKNOWLEDGEMENT}

The authors wish to acknowledge to Ir. Satya Graha Soemantri, M.Sc. for providing the iron ore concentrate. The authors also wish to express gratitude to the MEMR for funding the research as well as our colleagues who have assisted the research.

\section{REFERENCES}

Alizadeh, M. (2012) 'Effect of using oxygenenriched gas during induration process of iron ore pellets containing solid fuel', International Journal of Iron \& Steel Society of Iran, 9(2), pp. 27-31.
Atsushi, M., Uemura, $H$. and Sakaguchi, T. (2010) 'MIDREX processes', Kobelco Technology Review, (29), pp. 50-57.

Baig, S. and Murray, B. (2016) Cost effectiveness analysis of HYL and Midrex DRI technologies for the iron and steel-making industry. Duke University.

Chung, S. H., Kim, K. H. and Sohn, I. (2015) 'DRI from recycled iron bearing wastes for lower carbon in the blast furnace', ISIJ International, 55(6), pp. 1157-1164. doi: 10.2355/isijinternational.55.1157.

Dey, N. R., Prasad, A. K. and Singh, S. K. (2015) 'Energy survey of the coal based sponge iron industry', Case Studies in Thermal Engineering, 6, pp. 1-15. doi: 10.1016/j.csite.2015.04.001.

El-Hussiny, N. A. et al. (2015) 'Kinetics of direct reduction El-Baharia (Egypt) iron ore pellets in static bed via hydrogen', International Journal of Scientific \& Engineering Research, 6(10), pp. 870877.

Gorbachev, V. A., Abzalov, V. M. and Yurév, B. P. (2007) 'Conversion of magnetic to hematite in iron-ore pellets', Steel in Translation, 37(4), pp. 336-338.

Hashem, N. M. et al. (2015) 'Reduction kinetics of Egyptian iron ore by non coking coal', International Journal of Scientific \& Engineering Research, 6(3), pp. 846852.

Kawanari, M. et al. (2011) 'Enhancement of reduction rate of iron ore by utilizing iron ore / carbon composite consisting of fine iron ore particles and highly 
INDONESIAN MINING JOURNAL Vol. 22, No. 2, October $2019: 87$ - 98

thermoplastic carbon fiber material', ISIJ International, 51(8), pp. 1227-1233.

Man, Y. et al. (2014) 'Effect of particle size reduction on behavior in the iron orecoal composite pellets', Journal of Chemical and Pharmaceutical Research, 6(7), pp. 2484-2490.
Yu, W. et al. (2014) 'Effects of particle sizes of iron ore and coal on the strength and reduction of high phosphorus oolitic hematite-coal composite briquettes', ISIJ International, 54(1), pp. 56-62. doi: 10.2355/isijinternational.54.56. 